\title{
The Effect of Corporate Social Responsibility Activities on Investors' Heterogeneous Beliefs: A Study of Korea's Data Set
}

\author{
Hyun-Uk JUNG', Tae-Hyoung MUN², Young Ei KIM ${ }^{3}$
}

Received: July 18, 2020 Revised: August 23, 2020 Accepted: August 28, 2020

\begin{abstract}
This study analyzes the effect of corporate social responsibility (CSR) activity on investors' heterogeneous beliefs. The hypothesis of this study is based on the conflicting effects of CSR activities on firm value and earning's quality. Investors' heterogeneous beliefs used in the empirical analysis of this study are trading volume, and CSR activity is measured by the KEJI Index (Korea Economic Justice Institute Index). This study performs an empirical analysis using regression analysis including control variables. CSR activities are found to have a positive relationship with trading volume. This is consistent regardless of the low and high accounting information (earning's quality). It can be interpreted that Korea's CSR activity acts as an incentive to increase investors' heterogeneous beliefs about target companies. In other words, it implies that the investor judges CSR activities negatively when evaluating firm value. This study could have a policy implication in that it analyzes how CSR activities affect investors' decision-making. In other words, this study analyzed CSR activities from the perspective of shareholders. Therefore, this study is expected to provide useful information for policymaking by regulatory agencies. In particular, its contribution is to presents data that CSR activities can be a negative factor in evaluating firm values.
\end{abstract}

Keywords: CSR Activities, Trading Volume, Investors' Heterogeneous Beliefs, Firm Value, Earning’s Quality

JEL Classification Code: F13, G32, M49

\section{Introduction}

The purpose of this study is to analyze the relationship between Corporate Social Responsibility (hereinafter referred to as 'CSR') activities and investors' heterogeneous beliefs. Specifically, this study aims to empirically analyze the effect of CSR activities on investors' heterogeneous beliefs about target companies. Moskowitz (1972), Waddock and Graves (1997), and Tsoutsoura (2004) report that CSR

\footnotetext{
${ }^{1}$ First Author. Professor, Department of Business Administration, Dong-A University, Republic of Korea. Email: biglotos@dau.ac.kr

${ }^{2}$ Corresponding Author. Professor, Department of Business Administration, Mokwon University, Republic of Korea. [Postal Address: Doanbuk-ro 88, Seo-gu, Deajeon, 34520, Korea]

Email: mungini@mokwon.ac.kr

${ }^{3}$ Professor, Department of Business Administration, Seoul Digital University, Republic of Korea. Email: Kimyei@naver.com

(c) Copyright: The Author(s)

This is an Open Access article distributed under the terms of the Creative Commons Attribution Non-Commercial License (https://creativecommons.org/licenses/by-nc/4.0/) which permits unrestricted non-commercial use, distribution, and reproduction in any medium, provided the original work is properly cited.
}

activities are positively related to stock price and management performance. Cheng et al. (2006) report that CSR activities can reduce agent costs. Kim et al. (2012) report that CSR activities enhance the transparency and reliability of net income. These studies show that CSR activity is a positive factor in increasing firm value or decreasing earnings management (Moser \& Martin, 2012).

If a company uses limited resources for CSR activities with cost characteristics, it may not be able to make profitable investment decisions (Harrison \& Freeman, 1999; Pava \& Krausz, 1996). In this regard, they report that CSR activity has a negative relationship with firm value. Barnea and Rubin (2010) and Harjoto and Jo (2011) report that CSR activities can be used as a means to increase the private benefits of managers in companies with high information asymmetries between shareholders and managers. In particular, Prior et al. (2008) report that managers performing earnings management use CSR to deal with stakeholder activism and vigilance. Therefore, Prior et al. (2008) report that there is a positive relationship between CSR activity and earnings management. This indicates that CSR activity can be a negative factor for firm value and earnings' quality 
(Brammer \& Millington, 2005; Goldreyer \& Diltz, 1999; Orlitzy et al., 2003).

Prior studies related to investors' heterogeneous beliefs have reported that a high earning's quality and a low level of information asymmetry reduce an investor's heterogeneous beliefs for target companies (Ajinkya et al., 1991; Jung \& Moon, 2017; Ziebart, 1990). In addition, prior studies related to investors' heterogeneous beliefs analyzed the relationship between various firm-specific variables and investors' heterogeneous beliefs. However, no studies have analyzed the effects of CSR activities on investors' decision-making. Therefore, this study analyzes the relationship between CSR activities and investors' heterogeneous beliefs.

Investors' heterogeneous beliefs are measured as trading volume. And CSR activity is measured by the KEJI Index (Korea Economic Justice Institute Index). As a result of the analysis, we find that CSR activities have a positive relationship with trading volume. This indicates that high CSR activities in Korea are increasing investors' heterogeneous beliefs about the target companies. In other words, it implies that investors judge CSR activities as a negative factor in evaluating firm value.

We additionally analyze how CSR activity relates to the trading volume after dividing the sample into a group withlow earnings' quality and a group with high-earnings' quality. As a result of the analysis, we find that CSR activities have a positive relationship with trading volume regardless of the group having low or high earnings' quality. This suggests that direct investors judge CSR activity as a negative factor for firm value.

This study analyzes the information effect of CSR activities from the perspective of investors. In other words, this study is expected to provide useful information for the establishment of policy by regulators in that it analyzes CSR activities from the perspective of shareholders. This study has a policy implication in that it analyzes how CSR activities affect investors' decision-making. This study is contributing in that it suggests that CSR activities among negative studies related to CSR activities can be a negative factor in firm value evaluation.

The composition of this study is as follows. In Chapter 2, previous research and research hypothesis is presented. Chapter 3 presents the research model, variable measurement, and sample selection, and Chapter 4 presents the empirical analysis results. Finally, Chapter 5 presents the results of this study.

\section{Preliminary Research and Hypothesis Setting}

\subsection{Research Related to CSR Activities}

Moskowitz (1972) begins investigating the relationship between CSR activity and financial performance through stock price changes, revealing a study that companies with high levels of CSR activity would increase the Dow-Jones Index for six months. Waddock and Graves (1997) analyze the relationship between CSR activities and financial performance using the Time-Lag Model. As a result of the analysis, we find that CSR activities have a positive relationship with financial performance.

Nelling et al. (2009) show a direct relationship between CSR and financial performance, and prove the circular relationship using assets and dividend income and stock price growth. Tsoutsoura (2004) analyzes the relationship between CSR activity and profitability using the Domini 400 Social Index as a proxy for CSR activity. As a result of the analysis, CSR activities are found to have a direct causal relationship with the profitability of the company. Becchetti et al. (2007) report that companies included in the Domini 400 Social Index continue to show abnormal returns after the date of disclosure, but the stock price of companies that fall out of the Domini 400 Social Index decreases. Kim et al. (2012) report that companies with high performance on CSR activities show a low level of earnings adjustment. In particular, Kim et al. (2012) report that CSR activities enhance the transparency and reliability of net income. In this context, Cheng et al. (2006) report that CSR can reduce agency costs.

Transparency and reliability of net income are factors that lower information risk (Bhattacharya et al., 2012). Expanding this logic, it is suggested that CSR activities contribute to reducing information asymmetry (Ghoul et al., 2011). Harrison and Freeman (1999) and Pava and Krausz (1996) explain that excessive concentration of CSR activity can negatively affect firm value. They say that CSR activities are undesirable in terms of maximizing shareholder value. Barnea and Rubin (2010) and Harjoto and Jo (2011) report that managers of companies with high information asymmetries between shareholders and managers use CSR activities to increase their private benefits.

Prior et al. (2008) empirically analyze the relationship between earnings management and CSR activities in 593 firms in 26 countries. As a result of the analysis, it is reported that CSR activities have a positive relationship with earnings management. Regarding these results, Prior et al. (2008) report that managers performing earnings management use CSR activities to deal with stakeholder activism and vigilance. However, Chih et al. (2007) analyze 1,653 corporations in 46 countries and find that the effect of CSR activities on earnings management does not provide consistent results for each measure of earnings management. Summarizing these results, it can be interpreted that the effect of CSR activities on earning's quality or accounting information is not consistent across countries. 


\subsection{Setting Factors Affecting Investors' Heteroge- neous Beliefs (Trading Volume) and Hypotheses}

Beaver (1968) defines the information effect as the change in expectations that occurs as a result of an event. In this regard, Beaver (1968) explains that information effects can be analyzed through price changes in the stock market and trading volume changes. As prices reflect the expectations of many investors, price changes reflect changes in market expectations, and trading volume changes reflect changes in individual investors' expectations (Beaver, 1968; Ziebart, 1990). Therefore, Beaver (1968) explains that price changes and trading volume changes can occur in different directions.

According to economics, when new information reaches the market, transactions continue to occur until a new equilibrium price is formed. In economics, if there is a disagreement among investors regarding the intrinsic value of a company, it means that the trading volume increases, but when a consensus on the intrinsic value of a company is formed among investors, the trading volume decreases. In this context, previous studies related to investors 'heterogeneous beliefs use the trading volume as a proxy for investors' heterogeneous beliefs for investment target companies (Ajinkya et al., 1991; Bamber, 1987; Beaver, 1968; Karpoff, 1986; Morse, 1981; Ziebart, 1990). Morse (1981) explains that the trading volume before disclosure is caused by different beliefs in the signals of the disclosure, and this difference in belief is caused by an asymmetric distribution of information. In addition, Morse (1981) explains that the trading volume after disclosure occurs due to differences in interpretations of signals of disclosure.

Heterogeneity of beliefs among investors allows various interpretations of new information provided by companies, and various interpretations by investors result in increasing trading volume (Ajinkya et al., 1991; Bamber, 1987; Karpoff, 1986). This suggests that if the information asymmetry level of the target company is high, the investor's heterogeneous belief may increase. Ajinkya et al. (1991) analyze the relationship between the trading volume and the variance of analysts' earnings forecasts by measuring the variance of analysts' earnings forecasts as a proxy variable representing different levels of belief in a company's future stock returns (prospects). As a result of the analysis, the variance of analysts' earnings forecasts is found to be positively related to trading volume.

Similar results, Ziebart (1990) report that changes in the variance of analysts' earnings forecasts and revisions in analysts' earnings forecasts increase changes in abnormal trading volume. These results suggest that heterogeneity in investors' beliefs can be a decisive factor in trading volume (Ajinkya et al., 1991). Meanwhile, Bhattacharya et al. (2012) explain that high earning's quality acts as a factor to reduce information asymmetry (information risk). This suggests that high earning's quality can be a factor in reducing investors' heterogeneous beliefs. In this regard, Jung and Moon (2017) explain that high matching increases earning's quality and decreases investors' heterogeneous beliefs.

Kim et al. (2012) report that CSR activities contribute to enhancing transparency and reliability of net income. This suggests that high CSR activity will act as an incentive to reduce investors' heterogeneous beliefs. In this case, CSR activity is expected to be negatively related to investors' heterogeneous beliefs. However, Barnea and Rubin (2010) and Harjoto and Jo (2011) report that managers of companies with high information asymmetries between shareholders and managers use CSR to increase their private benefits. A high level of information asymmetry can be a requirement for earnings management (Dye, 1988; Trueman \& Titman, 1988). And Richardson (2000) suggests that a high level of information asymmetry leads to earnings management.

In this context, Prior et al. (2008) report that there is a positive relationship between CSR and earnings management. This suggests that CSR activities can act as an incentive to increase investors' heterogeneous beliefs about target companies. In other words, these results indicate that CSR activity can be positively related to investors' heterogeneous beliefs. Based on the different results related to CSR activities, the following null hypothesis is established in this study.

Hypothesis: CSR activity is not related to investors' heterogeneous beliefs.

\section{Research Methodology}

\subsection{Research Model}

In this study, to analyze the effect of CSR on investors' heterogeneous beliefs, a model such as equation (A. 1) is established.

If $\beta_{1}$ in Eq. (A. 1) gives a significant positive value, high CSR activity can be interpreted as increasing investors'

heterogeneous beliefs for the target company. However, if $\beta_{1}$ provides a significant negative value, high CSR activity can be interpreted as reducing investors' heterogeneous beliefs about the target company.

We include the following control variables in the model. Beaver (1968) explains that high profitability is a factor in increasing trading volume. We include ROA to control the effect of profitability on trading volume, and ROA is expected to have a positive relationship with trading volume. A study verifying the signal effect of dividends explains that dividends affect stock price (Ambarish et al., 1987; Baker et al., 1985; Benartzi et al,. 1997; Nissim \& Ziv, 2001;). The stock price is determined by the trading volume. In this case, dividends are expected to affect the trading volume, and DIV is included in the model. DIV is expected to have a negative relationship with the trading volume. 
Equation (A. 1)

\begin{tabular}{|c|c|c|}
\hline \multicolumn{3}{|r|}{$\begin{aligned} T V_{\mathrm{i}, \mathrm{t}}= & \beta_{0}+\beta_{1} \operatorname{CSR}_{\mathrm{i}, \mathrm{t}}+\beta_{2} \mathrm{ROA}_{\mathrm{i}, \mathrm{t}}+\beta_{3} D I V_{\mathrm{i}, \mathrm{t}}+\beta_{4} E X P_{\mathrm{i}, \mathrm{t}} \\
& +\beta_{5} A G E_{\mathrm{i}, \mathrm{t}}+\beta_{6} C F O_{\mathrm{i}, \mathrm{t}}+\beta_{7} S I Z E_{\mathrm{i}, \mathrm{t}}+\beta_{8} B I G F I R M_{\mathrm{i}, \mathrm{t}} \\
& +\beta_{9} L E V_{\mathrm{i}, \mathrm{t}}+\beta_{10} B O D_{\mathrm{i}, \mathrm{t}}+\beta_{11} E Q_{\mathrm{i}, \mathrm{t}}+\beta_{12} V D_{\mathrm{i}, \mathrm{t}} \\
& +\beta_{13} T S_{\mathrm{i}, \mathrm{t}}+\beta_{14} / C_{\mathrm{i}, \mathrm{t}}+\beta_{15} Y D_{\mathrm{i}, \mathrm{t}}+\beta_{16} I N D_{\mathrm{i}, \mathrm{t}}+\varepsilon\end{aligned}$} \\
\hline$T V$ & : & Trading Volume (TV1, TV2 and TV3) \\
\hline CSR & : & KEJI Index (Korea Economic Justice Institute Index) \\
\hline$R O A$ & : & Return On Asset (Income Before Income Taxes/Total Assets) \\
\hline$D N$ & : & Cash Dividends ( 1 if there is a cash dividend or 0 otherwise) \\
\hline EXP & : & Export Ratio \\
\hline$A G E$ & : & In (listed months) \\
\hline CFO & : & $\begin{array}{l}\text { Cash Flow from Operating Activities (cash flow from operating activities at the end of } \\
\text { the year (t)/sales during the one ( } \mathrm{t} \text { ) year) }\end{array}$ \\
\hline SIZE & : & In (total assets at the beginning of the year(t)) \\
\hline BIGFIRM & : & Big-Firm ( 1 if the auditor is big-firm 4, 0 for others) \\
\hline LEV & : & Debt Ratio (total debt at end of the year (t)/total assets at end of the year $(\mathrm{t})$ ) \\
\hline$B O D$ & : & $\begin{array}{l}\text { Ratio of Outside Directors (number of outside directors/number of registered } \\
\text { directors) }\end{array}$ \\
\hline$E Q$ & : & $\begin{array}{l}\text { Earning's Quality (quality of accruals (based on Dechow and Dichev (2002) } \\
\text { methodology) } \times(-1)\end{array}$ \\
\hline$V D$ & : & $\begin{array}{l}\text { Voluntary Disclosure Level (total number of voluntary disclosures during the one (t) } \\
\text { year/total assets at end of the year }(\mathrm{t}) \text { ) }\end{array}$ \\
\hline TS & : & Tax Benefits \\
\hline IC & : & Product Market Competition (Huffindal-Hirschman Index $(\mathrm{HHI}) \times(-1)$ ) \\
\hline$Y D$ & : & Year Dummy \\
\hline IND & : & Industry Dummy \\
\hline
\end{tabular}

EXP is included in the model to control the effect of the export ratio on the trading volume. If exports account for a high proportion of total sales, information asymmetry is likely to be high. Therefore, EXP is expected to have a positive relationship with trading volume.

AGE is included in the model to control the effect of the history of a company on trading volume. Companies with a long history are expected to have a lot of information known in the capital markets. We expect to have a negative relationship between AGE and trading volume. Jensen (1986) explains that high free cash flows can increase managerial discretion and cause agency problems. We include CFO in the model to control the effect of operating activity cash flow on the trading volume, and the regression sign of the $\mathrm{CFO}$ is expected to be a positive value. Bhushan (1989) reports that the size and the number of financial analysts (Analyst following) are positively related. This suggests that the information environment can be excellent for large companies. Therefore, we expect that the regression coefficient of SIZE will present a negative value. Becker et al. (1998) report that big six auditors provide higher audit quality than non-big six auditors. Therefore, in this study, BIGFIRM is included in the model to control the effect of audit quality on trading volume.

LEV is included in the model to control the effect of the company's financial risk on the trading volume, and the regression sign of LEV is expected to present a positive value. We include BOD in the model to control the effect of corporate governance on trading volume, and BOD is expected to have a positive relationship with trading volume. The quality of accruals is measured as a proxy for earning's 
quality (EQ) and included in the model. We expect earning's quality (EQ) to have a negative relationship with trading volume. Diamond and Verrecchia (1991) report that stock liquidity increases as the disclosure level increases. In this context, Jung and Moon (2017) report that there is a positive relationship between the amount of information disclosed and the trading volume. We measure the disclosure level of each company as a voluntary disclosure level (VD) to control the effect of the disclosure level of each company on the trading volume.

TS is included in the model to control the effects of corporate tax policies on trading volume. If there are tax benefits, net income will increase. In this case, TS is expected to have a positive relationship with the trading volume.

According to previous studies related to the degree of competition in the product market, it is reported that the competition in the product market acts as a mechanism of external corporate governance and weakens the risks of management (Hart, 1983). Therefore, in this study, IC is included in the model to control the effect of the external governance on trading volume. IC is expected to have a negative relationship with trading volume. And, YD and IND are included in the model to control the year and industry effects.

\subsection{Variable Measurement}

\subsubsection{Proxies of Investors' Heterogeneous Beliefs}

In this study, investors' heterogeneous beliefs are measured by trading volume. The trading volume is measured as in the following equations (A. 2), (A. 3) and (A. 4) (Bamber, 1987; Beaver, 1968; Jung \& Moon, 2017; Morse, 1981; Ziebart, 1990). First, trading volume1 (TV1) is as shown in equation (A. 2).

Although trading volume1 (TV1) in Equation (A. 2) represents average daily trading volume, it does not indicate whether an individual company's (i) trading volume on a specific ( $t$ ) day is a positive or a negative trading volume. In order to solve these limitations, in this study, additional trading volumes are measured as shown in equations (A. 3) and (A. 4).

The trading volume2 (TV2) in Eq. (A. 3) is measured by dividing the difference between the stock trading volume and the market's trading volume by the number of days the trading volume existed. In this case, if trading volume2 (TV2) is greater than ' 0 (zero)', it can be interpreted that a positive abnormal trading volume has occurred. Conversely, if trading volume2 (TV2) is less than ' 0 (zero)', it can be interpreted that a negative abnormal trading volume has occurred.

Equation (A. 2)

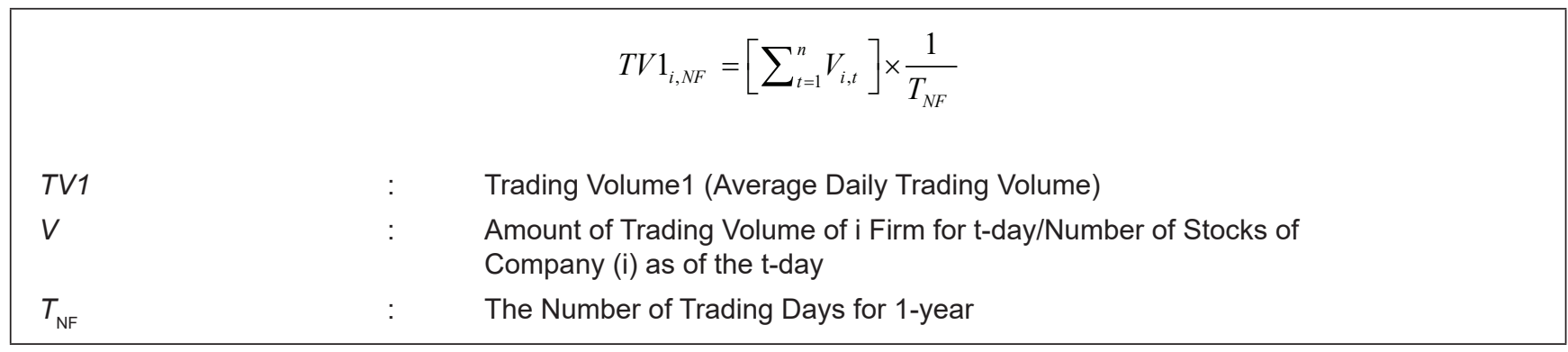

Equation (A. 3), (A. 4)

\begin{tabular}{|c|c|c|}
\hline & & $\begin{array}{c}T V 2=\left[\sum_{t=1}^{n}\left(V_{i, t}-V_{m, t}\right)\right] \times \frac{1}{T_{N F}} \\
T V 3=\left[\sum_{t=1}^{n} \frac{V_{i, t} / V_{m, t}}{\overline{V_{i, t} / V_{m, t}}}\right]\end{array}$ \\
\hline TV2 & : & Trading Volume2 \\
\hline TV3 & : & Trading Volume3 \\
\hline$V_{\mathrm{mt}}$ & : & $\begin{array}{l}\text { Total Trading Volume in Market for t-day/The Number of Listed Stocks in the Market } \\
\text { as of t-day }\end{array}$ \\
\hline$\overline{V_{i, t} / V_{m, t}}$ & : & $\begin{array}{l}\text { Expected Trading Volume Ratio of an Individual Company for t-day (Average Over } \\
\text { the Previous Year) }\end{array}$ \\
\hline
\end{tabular}


The trading volume 3 (TV3) in equation (A. 4) is measured by dividing the current average daily trading volume of an individual company by the average trading volume of the individual company for the previous year. If the trading volume3 (TV3) exceeds ' 1 (one)', it can be interpreted that a positive abnormal trading volume has occurred. If trading volume 3 (TV3) is less than ' 1 (one)', it can be interpreted that a negative abnormal trading volume has occurred.

\subsubsection{Proxies of Earnings' Quality (EQ)}

The quality of the accruals is measured based on the following equation (A. 5) in the model of Dechow and Dichev (2002). The absolute value of the residuals $(|\varepsilon|)$ in the following equation (A. 5) means the accruals that are not cashed. When the uncashed accrual $(|\varepsilon|)$ increases, earnings' quality decreases. In this regard, we measure earnings' quality as $((|\varepsilon|) \times(-1))$. It can be interpreted that earnings' quality increases as the value of $((|\varepsilon|) \times(-1))$ increases.

\subsubsection{Proxies of Product Market Competition (IC)}

In this study, the degree of competition in the product market is measured by the Hepindal-Hirschman Index (hereinafter referred to as "HHI"). HHI can be measured by the following equation. HHI measures the sales of individual companies divided by the sales of the entire industry on the basis of the same industry and is summed up by industry (Giroud \& Mueller, 2011; Grullon \& Michaely, 2007). In this case, it can be interpreted that a company with a high HHI value has a low degree of competition in the product market. Therefore, in this study, HHI is multiplied by ' $(-1)$ ' to measure the degree of competition in the product market. A company with a high level of competition in industry (IC, $(\mathrm{HHI}) \times(-1)$ can be interpreted as having a high level of competition in industry.

\subsection{Samples}

The samples for this study have been selected as companies that satisfy the following conditions from 2009 to 2013. In this case, the final sample is 1,334 (companyyear).

(1) Listed companies in the stock market from 2010 to 2014 excluding the financial industry

(2) Companies that can collect the KEJI index

(3) A company that can collect audit firms, financial statements and trading volume data from Kis-Value of NICE Co., Ltd.

(4) Companies with a closing date of December 31st

(5) Companies with positive capital and companies with unmodified-audit opinions

(6) Companies that can collect the number of registered directors, outside directors, and voluntary disclosures in the electronic disclosure system of the Financial Supervisory Service of Korea

Table 1 presents the sample selection process. Specifically, 3,949 companies (company-year) are found to satisfy condition (1). Of the 3,949 (company-year) companies, 2,236 (company-year) are found that did not meet conditions (2) and (3). There are 279 companies (company-years) that did not meet conditions (4), (5), and (6). Therefore, the final sample is 1,334 (company-year).

Equation (A. 5)

\begin{tabular}{|c|c|c|}
\hline & & $T C A_{i, t}=\beta_{0}+\beta_{1} C F O_{i, t-1}+\beta_{2} C F O_{i, t}+\beta_{3} C F O_{i, t+1}+\varepsilon$ \\
\hline TCA & : & $\begin{array}{l}((\triangle \text { Current Assets- } \triangle \text { Cash })-(\triangle \text { Current Liabilities- } \triangle \text { Current Maturities of Long- } \\
\text { Term Debt })) / \text { Average Total Assets }\end{array}$ \\
\hline CFO & : & Operating Cash Flow / Average Total Assets \\
\hline
\end{tabular}

\section{Equation (A. 6)}

$$
\sum_{t=1}^{n} S_{i, j, t}^{2}
$$

$\mathrm{S}$ is the market share in industry based on one year (t)'s sales of i companies included in industry. 
Table 1: Organization of the Sample

\begin{tabular}{|l|c|}
\hline Conditions & Company-year \\
\hline Companies that satisfy the conditions (1) & 3,949 \\
\hline - Companies that do not meet the conditions (2) and (3) & $-2,236$ \\
\hline- Companies that do not satisfy conditions (4), and (5) and (6) & -279 \\
\hline Final sample & 1,334 \\
\hline
\end{tabular}

Table 2: Descriptive Statistics of Variables

\begin{tabular}{|l|c|c|c|c|c|c|c|c|}
\hline \multicolumn{2}{|l|}{ Variables } & Mean & Std & Min & $\mathbf{2 5 \%}$ & Median & $\mathbf{7 5 \%}$ & Max \\
\hline \multirow{3}{*}{$T V$} & $T V 1$ & 0.0092 & 0.0153 & 0.0001 & 0.0019 & 0.0043 & 0.0099 & 0.1455 \\
\cline { 2 - 8 } & $T V 2$ & -0.0037 & 0.0154 & -0.0171 & -0.0108 & -0.0075 & -0.0024 & 0.1296 \\
\cline { 2 - 8 } & $T V 3$ & 0.8090 & 1.3448 & 0.0073 & 0.1753 & 0.4001 & 0.8931 & 15.4967 \\
\hline CSR & 48.2775 & 7.2841 & 35.8000 & 43.3350 & 46.0700 & 50.2425 & 70.5300 \\
\hline$R O A$ & 0.0551 & 0.0782 & -0.5751 & 0.0182 & 0.0528 & 0.0951 & 0.4225 \\
\hline$D I V$ & 0.8396 & 0.3671 & 0.0000 & 1.0000 & 1.0000 & 1.0000 & 1.0000 \\
\hline EXP & 0.2419 & 0.2974 & 0.0000 & 0.0000 & 0.0794 & 0.4487 & 1.0000 \\
\hline AGE & 3.5028 & 0.5748 & 0.6931 & 3.4012 & 3.6376 & 3.8502 & 4.7449 \\
\hline CFO & 0.0730 & 0.1324 & -0.7283 & 0.0100 & 0.0638 & 0.1225 & 1.2091 \\
\hline SIZE & 26.6726 & 1.4349 & 23.1834 & 25.6480 & 26.3925 & 27.4188 & 32.3055 \\
\hline BIGFIRM & 0.7234 & 0.4475 & 0.0000 & 0.0000 & 1.0000 & 1.0000 & 1.0000 \\
\hline LEV & 0.4100 & 0.1846 & 0.0005 & 0.2607 & 0.4088 & 0.5569 & 0.9109 \\
\hline EQ & -0.0568 & 0.0599 & -0.7983 & -0.0774 & -0.0395 & -0.0167 & 0.0000 \\
\hline BOD & 0.4768 & 0.4996 & 0.0000 & 0.0000 & 0.0000 & 1.0000 & 1.0000 \\
\hline VD & 0.0464 & 0.1070 & 0.0000 & 0.0000 & 0.0000 & 0.0395 & 1.6822 \\
\hline$T S$ & -0.0035 & 0.0356 & -0.7611 & -0.0053 & -0.0007 & 0.0044 & 0.1173 \\
\hline$I C$ & -0.1235 & 0.1318 & -0.9070 & -0.1567 & -0.0838 & -0.0314 & -0.0063 \\
\hline
\end{tabular}

Notes: TV1: trading volume1; TV2: trading volume2; TV3: trading volume3; CSR: KEJI index(Korea Economic Justice Institute Index); $R O A$ : return on asset (income before income taxes/total assets); DIV: cash dividends (1 if there is a cash dividend or 0 otherwise); EXP: export ratio; AGE: In (Listed months); CFO: cash flow from operating activities (cash flow from operating activities at the end of the year(t)/ sales during the one (t) year); SIZE: In (total assets at the beginning of the year (t)); BIGFIRM: Big-Firm (1 if the auditor is big-firm 4, 0 for others); LEV: debt ratio (total debt at end of the year ( $\mathrm{t}$ )/total assets at end of the year ( $\mathrm{t}$ )); BOD: ratio of outside directors (number of outside directors/number of registered directors); EQ: earning's quality (quality of accruals (based on Dechow and Dichev (2002) methodology) $\times$ $(-1))$; VD: voluntary disclosure level (total number of voluntary disclosures during the one (t) year/total assets at end of the year ( $\mathrm{t})$ ); TS: tax benefits; IC: product market competition (Huffindal-Hirschman Index $(\mathrm{HHI}) \times(-1)$ ).

\section{Empirical Results}

\subsection{Descriptive Statistics and Correlation of Major Variables}

Table 2 shows the descriptive statistics of each variable. As the descriptive statistics, the mean (median), standard deviation, and quartile of each variable are presented. According to Table 2, the means (medians) of TV1, TV2, and TV3 are 0.0092 (0.0043), -0.0037 (-0.0075), and 0.8090 (0.4001), respectively. In particular, the means and medians of $T V 2$ and TV3 indicating abnormal trading volume are smaller than 0 (zero) and 1 (one), respectively. This indicates that more than half of the sample companies have negative abnormal trading volumes.

The mean and median of CSR are 48.2775 and 46.0700, respectively. The mean of CSR seems to be similar to the median. The mean (median) of $R O A$ is 0.0551 (0.0528), and the $D I V$ mean (median) is 0.8396 (1.0000). In particular, since the median of $D I V$ is 1.0000 , more than half of the samples are judged to pay dividends. The means (medians) of EXP and $A G E$ are 0.2419 (0.0794) and 3.5028 (3.6376), respectively. The means (medians) of CFO, SIZE, and BIGFIRM are 0.0730 (0.0638), 26.6726 (26.3925), and $0.7234(1.0000)$. And the $L E V$ mean and median are 0.4100 and 0.4088 , respectively. The mean (median) of $E Q$ is 
$-0.0568(-0.0395)$, and the mean (median) of $B O D$ is 0.4768 (0.0000). The means (medians) of $V D$ and $T S$ are 0.0464 $(0.0000)$ and $-0.0035(-0.0007)$, respectively. The mean (median) of the $I C$ is $-0.1235(-0.0838)$.

Table 3 shows the Pearson correlation coefficient between variables used in the empirical test. Based on Table 3, CSR is shown to have a significant negative (-) correlation with $T V 2$ and $T V 3$, but $T V 1$ does not have a significant correlation with CSR. As this is a result of not controlling the effect on the trading volume, it is considered that a more in-depth test including control variables is necessary.

$T V$ has been shown to have a significant negative correlation with ROA, DIV, CFO, SIZE, BIGFIRM, and TS. $T V 2$ is found to have a significant negative correlation with $B O D$. But $T V 1$ and $T V 2$ are found to have no significant correlation with $B O D$.

Table 3: Correlation Coefficient

\begin{tabular}{|c|c|c|c|c|c|c|c|}
\hline & TV1 & TV2 & TV3 & CSR & ROA & DIV & EXP \\
\hline TV2 & $0.9853^{* * *}$ & & & & & & \\
\hline TV3 & $0.9699^{* * *}$ & $0.9741^{* \star *}$ & & & & & \\
\hline CSR & 0.0084 & $-0.1126^{* \star *}$ & $-0.0652^{* *}$ & & & & \\
\hline$R O A$ & $-0.1293^{* * *}$ & $-0.1285^{\star \star *}$ & $-0.1192^{\star * \star}$ & $0.0627^{\star *}$ & & & \\
\hline$D I V$ & $-0.2094^{* * *}$ & $-0.2056^{* * *}$ & $-0.1955^{\star \star \star}$ & $0.0744^{* \star *}$ & $0.4149^{* * *}$ & & \\
\hline EXP & $0.1014^{* * *}$ & $0.1121^{* \star *}$ & $0.1176^{* * *}$ & $-0.0736^{* * *}$ & 0.0187 & 0.0191 & \\
\hline$A G E$ & -0.0123 & -0.0024 & -0.0107 & $-0.0622^{* *}$ & $-0.0983^{* * *}$ & $0.0525^{*}$ & $0.0477^{*}$ \\
\hline CFO & $-0.0998^{* \star *}$ & $-0.1264^{* * *}$ & $-0.1082^{* \star *}$ & $0.1782^{* * *}$ & $0.3290^{* \star *}$ & $0.2116^{* * *}$ & -0.0418 \\
\hline SIZE & $-0.1813^{* * *}$ & $-0.1816^{\text {*t* }}$ & $-0.1821^{* \star *}$ & $0.1656^{\text {**** }}$ & 0.0303 & $0.1774^{* * *}$ & $0.0923^{* * * *}$ \\
\hline BIGFIRM & $-0.1395^{\star * *}$ & $-0.1392^{* * *}$ & $-0.1472^{\star \star \star}$ & $0.1126^{\star \star *}$ & $0.0893^{\star \star *}$ & $0.1589^{\star * \star}$ & -0.0407 \\
\hline$\angle E V$ & $0.1338^{* * \star}$ & $0.1452^{* \star *}$ & $0.1411^{* * *}$ & $-0.1634^{* * *}$ & $-0.4069^{* \star *}$ & $-0.2464^{* \star *}$ & $0.0805^{* * *}$ \\
\hline$E Q$ & -0.0238 & -0.041 & -0.0332 & $0.0755^{* * *}$ & $0.1216^{* * *}$ & $0.1961^{* \star *}$ & -0.0058 \\
\hline$B O D$ & -0.0106 & $-0.047^{*}$ & -0.0375 & $0.3383^{* * *}$ & 0.0056 & 0.0246 & 0.0122 \\
\hline$V D$ & 0.0090 & 0.0153 & 0.0076 & -0.0352 & $-0.0873^{* * *}$ & $-0.0487^{*}$ & -0.0281 \\
\hline TS & $-0.0907^{* \star *}$ & $-0.0923^{* * *}$ & $-0.087^{* * *}$ & 0.0309 & $0.3708^{* \star \star}$ & $0.2534^{\star \star \star}$ & $0.0505^{*}$ \\
\hline \multirow[t]{2}{*}{ IC } & $0.0499^{*}$ & 0.043 & $0.0475^{\star}$ & 0.0000 & -0.0361 & -0.0034 & $-0.0956^{* * *}$ \\
\hline & AGE & CFO & SIZE & BIGFIRM & LEV & $E Q$ & BOD \\
\hline CFO & $-0.1159^{* * *}$ & & & & & & \\
\hline$S I Z E$ & 0.0120 & $0.0769^{* * *}$ & & & & & \\
\hline BIGFIRM & -0.0264 & $0.0867^{* \star *}$ & $0.3735^{\star \star \star}$ & & & & \\
\hline$L E V$ & 0.0225 & $-0.3875^{\star \star * *}$ & $0.2127^{\star \star \star}$ & 0.0266 & & & \\
\hline$E Q$ & $0.0460^{*}$ & 0.039 & $0.0906^{\star \star \star}$ & $0.0630^{* *}$ & $-0.0620^{* *}$ & & \\
\hline$B O D$ & $-0.0559^{* *}$ & $0.0667^{* *}$ & $0.2651^{* \star *}$ & 0.0400 & -0.0063 & $0.0633^{* *}$ & \\
\hline$V D$ & 0.0066 & $-0.0718^{* * *}$ & $0.2676^{\star \star \star}$ & $0.0586^{* *}$ & $0.1900^{* * *}$ & 0.0113 & 0.0019 \\
\hline TS & -0.0235 & $0.1450^{* * *}$ & 0.0136 & $0.0565^{* *}$ & $-0.2269^{* * *}$ & $0.1320^{* * *}$ & -0.0003 \\
\hline \multirow[t]{2}{*}{ IC } & 0.0392 & $-0.0457^{*}$ & $-0.3231^{\star \star *}$ & $-0.1142^{* * *}$ & -0.0072 & 0.0138 & $-0.0619^{* *}$ \\
\hline & VD & TS & IC & & & & \\
\hline TS & -0.0345 & & & & & & \\
\hline IC & -0.0328 & 0.0008 & & & & & \\
\hline
\end{tabular}

Notes: 1 . Refer to $<$ Table $2>$ for variable definitions. $2 .{ }^{*} p<0.1,{ }^{* *} p<0.05,{ }^{* * *} p<0.001$. 
EXP and $L E V$ appear to have a significant positive $(+)$ correlation with $T V$. The $I C$ appears to have a significant positive $(+)$ correlation with $T V 1$ and $T V 3$. On the other hand, each trading volume measurement has a significant positive $(+)$ correlation.

\subsection{Results on Hypothesis}

Table 4 is the result of analyzing the hypothesis of this study. Specifically, Model 1 in Table 4 is the result of measuring and analyzing the dependent variable with $T V 1$. Models 2 and 3 are the results of analyzing the dependent variables by measuring TV2 and TV3. Based on Table 4, the regression coefficient of $C S R$ shows a significant positive
(+) value in each model. This indicates that CSR activity is positively related to trading volume. In other words, high CSR activity can be interpreted as increasing investors' heterogeneous beliefs about target companies.

The regression coefficients of $D I V$ and SIZE show significant negative values in each model. The regression coefficient of BIGFIRM is found to be significant in each model. These results suggest that dividends, size, and bigfirm are factors that decrease investors' different beliefs. The regression coefficient of $L E V$ represents a significant positive value. The high debt ratio seems to be a factor in increasing the trading volume.

Table 4: Regressions for the Effect of CSR Activities on Investors' Heterogeneous Beliefs

\begin{tabular}{|c|c|c|c|c|c|c|c|c|c|}
\hline \multirow{3}{*}{\begin{tabular}{|l} 
\\
Intercept
\end{tabular}} & \multicolumn{3}{|c|}{ MODEL 1: TV1 } & \multicolumn{3}{|c|}{ MODEL 2: TV2 } & \multicolumn{3}{|c|}{ MODEL 3: TV3 } \\
\hline & Coefficient & \multicolumn{2}{|c|}{ t-statistic } & Coefficien & \multicolumn{2}{|c|}{ t-statistic } & Coefficien & \multicolumn{2}{|c|}{ t-statistic } \\
\hline & 0.0566 & 7.14 & *** & 0.0473 & 5.98 & so* & 5.2508 & 6.80 & $*+*$ \\
\hline CSR & 0.0004 & 3.01 & $* * *$ & 0.0004 & 3.01 & $* * *$ & 0.0298 & 2.63 & $\ldots$ \\
\hline$R O A$ & -0.0002 & -0.03 & & -0.0002 & -0.03 & & 0.1475 & 0.27 & \\
\hline DIV & -0.0055 & -3.31 & $* * *$ & -0.0055 & -3.31 & $* * *$ & -0.4450 & -3.07 & $\ldots$ \\
\hline EXP & 0.0060 & 3.95 & *** & 0.0060 & 3.95 & wat & 0.5500 & 3.77 & 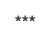 \\
\hline$A G E$ & 0.0001 & -0.08 & & 0.0001 & -0.08 & & -0.0060 & -0.13 & \\
\hline CFO & -0.0003 & -0.10 & & -0.0003 & -0.10 & & 0.0615 & 0.26 & \\
\hline SIZE & -0.0025 & -6.51 & $* * *$ & -0.0025 & -6.51 & $* * *$ & -0.2155 & -5.92 & $\ldots$ \\
\hline BIGFIRM & -0.0020 & -1.81 & * & -0.0020 & -1.81 & * & -0.2045 & -1.99 & * \\
\hline LEV & 0.0119 & 4.55 & $* * *$ & 0.0119 & 4.55 & $* * *$ & 1.1046 & 4.71 & $\ldots$ \\
\hline$E Q$ & 0.0064 & 0.89 & & 0.0064 & 0.89 & & 0.5099 & 0.86 & \\
\hline$B O D$ & -0.0004 & -0.13 & & -0.0004 & -0.13 & & -0.0605 & -0.22 & \\
\hline$V D$ & 0.0045 & 1.59 & & 0.0045 & 1.59 & & 0.3470 & 1.43 & \\
\hline TS & -0.0143 & -0.65 & & -0.0143 & -0.65 & & -1.2910 & -0.70 & \\
\hline IC & -0.0022 & -0.86 & & -0.0022 & -0.86 & & -0.1552 & -0.70 & \\
\hline$Y D$ & \multicolumn{3}{|c|}{ Included } & \multicolumn{3}{|c|}{ Included } & \multicolumn{3}{|c|}{ Included } \\
\hline IND & \multicolumn{3}{|c|}{ Included } & \multicolumn{3}{|c|}{ Included } & \multicolumn{3}{|c|}{ Included } \\
\hline F-value & \multicolumn{3}{|c|}{$6.96^{* * *+}$} & \multicolumn{3}{|c|}{$6.47^{* * * *}$} & \multicolumn{3}{|c|}{$4.57^{* \star * *}$} \\
\hline Adj. $R^{2}$ & \multicolumn{3}{|c|}{0.1202} & \multicolumn{3}{|c|}{0.1274} & \multicolumn{3}{|c|}{0.1183} \\
\hline
\end{tabular}

Notes: 1 . Refer to $<$ Table $2>$ for variable definitions. $2 .{ }^{*} p<0.1,{ }^{* *} p<0.05,{ }^{* * *} p<0.001$. 
Table 5: Relationship between CSR activities and investors' heterogeneous beliefs based on group with low-earning's quality

\begin{tabular}{|c|c|c|c|c|c|c|c|c|c|}
\hline \multirow[b]{3}{*}{ Intercept } & \multicolumn{3}{|c|}{ MODEL 1: TV1 } & \multicolumn{3}{|c|}{ MODEL 2: TV2 } & \multicolumn{3}{|c|}{ MODEL 3: TV3 } \\
\hline & Coefficient & \multicolumn{2}{|c|}{ t-statistic } & Coefficient & \multicolumn{2}{|c|}{ t-statistic } & Coefficient & \multicolumn{2}{|c|}{ t-statistic } \\
\hline & 0.0614 & 4.74 & 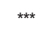 & 0.0522 & 4.03 & 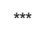 & 5.9142 & 4.51 & tot \\
\hline CSR & 0.0003 & 1.95 & * & 0.0003 & 1.95 & * & 0.0257 & 1.87 & * \\
\hline$R O A$ & -0.0015 & -0.17 & & -0.0015 & -0.17 & & -0.0526 & -0.07 & \\
\hline DIV & -0.0054 & -2.68 & $* * *$ & -0.0054 & -2.68 & $+n$ & -0.4239 & -2.50 & ** \\
\hline$E X P$ & 0.0064 & 3.12 & $+\cdots$ & 0.0064 & 3.12 & sto & 0.5846 & 3.05 & tot \\
\hline$A G E$ & 0.0013 & 1.71 & * & 0.0013 & 1.71 & * & 0.0963 & 1.28 & \\
\hline CFO & 0.0028 & 0.72 & & 0.0028 & 0.72 & & 0.2717 & 0.74 & \\
\hline SIZE & -0.0027 & -4.42 & $n$ & -0.0027 & -4.42 & 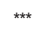 & -0.2438 & -4.03 & tot \\
\hline BIGFIRM & -0.0028 & -1.81 & * & -0.0028 & -1.81 & * & -0.2679 & -1.89 & * \\
\hline$\angle E V$ & 0.0116 & 3.06 & $+*$ & 0.0116 & 3.06 & tot & 1.0452 & 3.08 & 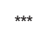 \\
\hline$B O D$ & -0.0032 & -0.60 & & -0.0032 & -0.60 & & -0.2582 & -0.59 & \\
\hline$V D$ & 0.0058 & 1.42 & & 0.0058 & 1.42 & & 0.4471 & 1.33 & \\
\hline$T S$ & -0.0181 & -0.68 & & -0.0181 & -0.68 & & -1.6731 & -0.73 & \\
\hline IC & -0.0027 & -0.74 & & -0.0027 & -0.74 & & -0.2345 & -0.71 & \\
\hline$Y D$ & \multicolumn{3}{|c|}{ Included } & \multicolumn{3}{|c|}{ Included } & \multicolumn{3}{|c|}{ Included } \\
\hline ICODE & \multicolumn{3}{|c|}{ Included } & \multicolumn{3}{|c|}{ Included } & \multicolumn{3}{|c|}{ Included } \\
\hline F-value & \multicolumn{3}{|c|}{$4.15^{\text {tht }}$} & \multicolumn{3}{|c|}{$5.92^{+*+*}$} & \multicolumn{3}{|c|}{$3.85^{n+* x}$} \\
\hline Adj. $R^{2}$ & \multicolumn{3}{|c|}{0.1492} & \multicolumn{3}{|c|}{0.1643} & \multicolumn{3}{|c|}{0.1445} \\
\hline
\end{tabular}

Notes: 1. Refer to $<$ Table $2>$ for variable definitions.2. ${ }^{*} p<0.1,{ }^{* *} p<0.05,{ }^{* * *} p<0.001$.

Summarizing the results in Table 4, it is found that there is a positive relationship between CSR activity and trading volume. This suggests that high CSR activity is a factor in increasing investors' heterogeneous beliefs about the target companies. These results can be interpreted in that Korean investors judge CSR activity as a negative factor when evaluating firm value.

\subsection{Additional Test}

Table 5 and Table 6 below are the results of analyzing the effect of CSR activity on trading volume after dividing the sample into a group with low-earnings and a group with high-earning's quality. Table 5 is the result of analyzing the relationship between CSR activity and trading volume for the group with low earnings 'quality, and Table 6 is the result of analyzing the relationship between CSR activity and trading volume for the group with high earnings' quality. Model 1, Model 2, and Model 3 of Table 5 and Table 6 are the results of analysis by setting $T V 1, T V 2$, and $T V 3$ as dependent variables.

Looking at the results of the analysis, the regression coefficients of CSR show significant positive values in all models in Table 5 and Table 6 . This can be interpreted that CSR activity acts as a factor to increase investors' heterogeneous beliefs regardless of earning's quality. In other words, this implies that the investor judges CSR activities negatively regardless of the accounting information of the target company. 
Table 6: Relationship Between CSR Activities and Investors' Heterogeneous Beliefs Based on Group with High-Earning's Quality

\begin{tabular}{|c|c|c|c|c|c|c|c|c|c|}
\hline \multirow{3}{*}{\begin{tabular}{|l} 
\\
Intercept
\end{tabular}} & \multicolumn{3}{|c|}{ MODEL 1: TV1 } & \multicolumn{3}{|c|}{ MODEL 2: TV2 } & \multicolumn{3}{|c|}{ MODEL 3: TV3 } \\
\hline & Coefficient & \multicolumn{2}{|c|}{ t-statistic } & \multirow{2}{*}{$\begin{array}{c}\text { Coefficien } \\
0.0436\end{array}$} & \multicolumn{2}{|c|}{ t-statistic } & \multirow{2}{*}{$\begin{array}{c}\text { Coefficien } \\
4.7237\end{array}$} & \multicolumn{2}{|c|}{ t-statistic } \\
\hline & 0.0528 & 4.94 & *** & & 4.07 & $\cdots$ & & 4.88 & $\ldots$ \\
\hline CSR & 0.0005 & 2.32 & ** & 0.0005 & 2.32 & ** & 0.0348 & 1.84 & * \\
\hline$R O A$ & -0.0015 & -0.14 & & -0.0015 & -0.14 & & 0.1818 & 0.20 & \\
\hline DIV & -0.0055 & -1.85 & * & -0.0055 & -1.85 & * & -0.4630 & -1.73 & * \\
\hline EXP & 0.0057 & 2.41 & ** & 0.0057 & 2.41 & ** & 0.5392 & 2.28 & * \\
\hline$A G E$ & -0.0013 & -1.68 & * & -0.0013 & -1.68 & * & -0.1037 & -1.61 & \\
\hline CFO & -0.0041 & -1.26 & & -0.0041 & -1.26 & & -0.1545 & -0.56 & \\
\hline SIZE & -0.0023 & -4.47 & $* *$ & -0.0023 & -4.47 & *** & -0.1971 & -4.08 & $\ldots$ \\
\hline BIGFIRM & -0.0015 & -0.88 & & -0.0015 & -0.88 & & -0.1513 & -0.98 & \\
\hline LEV & 0.0124 & 3.33 & $* *$ & 0.0124 & 3.33 & *** & 1.1965 & 3.59 & $\ldots$ \\
\hline$B O D$ & 0.0018 & 0.41 & & 0.0018 & 0.41 & & 0.0651 & 0.19 & \\
\hline$V D$ & 0.0033 & 0.80 & & 0.0033 & 0.80 & & 0.2775 & 0.71 & \\
\hline$T S$ & 0.0174 & 0.55 & & 0.0174 & 0.55 & & 1.7924 & 0.70 & \\
\hline IC & -0.0016 & -0.41 & & -0.0016 & -0.41 & & -0.0791 & -0.24 & \\
\hline$Y D$ & \multicolumn{3}{|c|}{ Included } & \multicolumn{3}{|c|}{ Included } & \multicolumn{3}{|c|}{ Included } \\
\hline$I C O D E$ & \multicolumn{3}{|c|}{ Included } & \multicolumn{3}{|c|}{ Included } & \multicolumn{3}{|c|}{ Included } \\
\hline F-value & \multicolumn{3}{|c|}{$3.74^{* * *}$} & \multicolumn{3}{|c|}{$3.35^{* \star *}$} & \multicolumn{3}{|c|}{$3.36^{* * *}$} \\
\hline Adj. $R^{2}$ & \multicolumn{3}{|c|}{0.1216} & \multicolumn{3}{|c|}{0.1198} & \multicolumn{3}{|c|}{0.1147} \\
\hline
\end{tabular}

Notes: 1 . Refer to $<$ Table $2>$ for variable definitions.

2. ${ }^{*} p<0.1,{ }^{* *} p<0.05,{ }^{* * *} p<0.001$.

\section{Conclusion}

This study has analyzed the effect of CSR activity on investors' heterogeneous beliefs. This study has empirically analyzed the effect of CSR activities on investors' heterogeneous beliefs about target companies. The effect of CSR activities on firm values and accounting information does not provide consistent results across countries. In studies related to investors 'heterogeneous beliefs, high earning's quality and low level of information asymmetry act as factors to reduce investors' heterogeneous beliefs. However, no research has analyzed the effects of CSR activities on investors' decision-making. Therefore, this study has empirically analyzed the effect of CSR activities on investors' heterogeneous beliefs about target companies.
In this study, investors' heterogeneous beliefs are measured as the trading volume, and the KEJI Index (Korea Economic Justice Institute Index) is used for CSR activities. As a result of the analysis, it is found that CSR activities increase the trading volume. This indicates that high CSR activities in Korea are increasing investors' heterogeneous beliefs about the target companies. In other words, it implies that investors judge CSR activities as a negative factor in evaluating firm value. In addition, this study analyzes the effect of CSR activity on trading volume after dividing the sample into a group with low earnings 'quality and a group with high earnings' quality. As a result of the analysis, it is found that CSR activity increases the trading volume in both the group with low-earnings 'quality and the group with high-earnings' quality. This suggests that direct investors judge CSR activity as a negative factor for firm value. 
This study analyzes the information effect of CSR activities from the perspective of investors. In other words, this study is expected to provide useful information for the establishment of policy by regulators in that it analyzes CSR activities from the perspective of shareholders. This study has a policy implication in that it analyzes how CSR activities affect investors' decision-making. This study is contributing in that it suggests that CSR activities among negative studies related to CSR activities can be a negative factor in firm value evaluation.

\section{References}

Ajinkya, B. B., Atiase, R. K., \& Gift, M. J. (1991). Volume of Trading and the Dispersion in Financial Analysts' Earnings Forecasts. The Accounting Review, 66(2), 389-401.

Ambarish. R., John, K., \& Williams, J. (1987). Efficient signaling with dividends and investments. Journal of Finance, 42(2), 321-343.

Baker, H. K., Farrelly, G. E., \& Edleman, R. B. (1985). A survey of management views on dividend policy. Financial Management, 14, 1007-1034

Bamber, L. S. (1987). Unexpected Earnings, Firm Size, and Trading Volume around Quarterly Earnings Announcements. The Accounting Review, 62(3), 510-532.

Barnea, A., \& Rubin, A. (2010). Corporate social responsibility as a conflict between shareholders. Journal of Business Ethics, 97(1), 71-86.

Beaver. W. (1968). The Information Content of Annual Earnings Announcements. Journal of Accounting Research, 6, 67-92.

Becchetti, L., Ciciretti, R., \& Hansan, I. (2012). Corporate Social Responsibility and Shareholder's Value. Journal of Business Research, 65(11), 1628-1635.

Becker, C. L., DeFond, M. L., Jiambalvo, J., \& Subramanyam, K. R. (1998). The effect of audit quality on earnings management. Contemporary Accounting Research, 15(1), 1-24.

Benartzi, S., Michaely, R., \& Thaler, R. (1997). Do changes in dividends signal the future or the past? Journal of Finance, 52(3), 1007-1034.

Bhattacharya, N., Ecker, F., Olsson, P., \& Schipper, K. (2012). Direct and Mediated Associations among Earnings Quality, Information Asymmetry, and the Cost of Equity. The Accounting Review, 87(2), 449-482.

Bhushan, R. (1989). Firm Characteristics and Analyst Following. Journal of Accounting and Economics, 11(2/3), 255-274.

Brammer, S., \& Millington, A. (2006). Firm Size, Organizational Visibility and Corporate Philanthropy: An Empirical Analysis. Business Ethics: A European Review, 15(1), 6-18.

Cheng, A., Collins, D., \& Huang, H. (2006). Shareholder rights, financial disclosure and the cost of equity capital. Review of Quantitative Finance \& Accounting, 27(2), 175-204
Chih, H. L., Shen, C. H., \& Kang, F. C. (2008). Corporate Social Responsibility, Investor Protection, and Earnings Management: Some International Evidence. Journal of Business Ethics, 79, 179-198. https://doi.org/10.1007/s10551-007-9383-7

Dechow, P. M., \& Dichev, I. (2002). The Quality of Accruals and Earnings: The Role of Accrual Estimation Errors. The Accounting Review, 77(Supplement), 35-59.

Diamond, D., \& Verrecchia, R. (1991). Disclosure, Liquidity, and the Cost of Capital. The Journal of Finance, 46(4), 1325-1360.

Dye, R. (1988). Earnings Management in an Overlapping Generations Model. Journal of Accounting Research, 26(2), 195-235.

Giroud, X., \& Mueller, H. (2011). Corporate Governance, Product Market Competition, and Equity Prices. Journal of Finance, 66(2), 563-600.

Goldreyer, E. F., \& Diltz, D. (1999). The Performance of Socially Responsible Mutual Fund: Incorporating Sociopolitical Information in Portfolio Selection. Managerial Finance, 25(1), 23-36.

Grullon, G., \& Michaely, R. (2007). Corporate Payout Policy and Product Market Competition. SSRN Electronic Journal. DOI: 10.2139/ssrn. 972221

Harjoto, M. A., \& Jo, H. (2011). Corporate governance and CSR nexus. Journal of Business Ethics, 100(1), 45-67.

Harrison, J. S. \& Freeman, R. E. (1999). Stakeholders, Social Responsibility and Performance: Empirical Evidence and Theoretical Perspective. Academy of Management Journal, 42(5), 479-485

Hart, O. D. (1983). The Market Mechanism as an Incentive Scheme. The Bell Journal of Economics, 14(2), 366-382.

Jensen, M. C. (1986). Agency Costs of Free Cash Flow, Corporate Finance, and Takeovers. American Economic Review, 76(2), 323-329.

Jung, H., \& Moon, S. (2017). Matching Level and Investors' Heterogeneous Beliefs. The Journal of Applied Business Research, 33(3), 451-465.

Karpoff, J. M. (1986). A Theory of Trading Volume. The Journal of Finance, 41(5), 1069-1087.

Kim, Y., Park, M. S., \& Wier, B. (2012). Is earnings quality associated with corporate social responsibility?. The Accounting Review, 87(3), 761-796.

Morse, D. (1981). Price and Trading Volume Reaction Surrounding Earnings Announcements: A Closer Examination. Journal of Accounting Research, 19(2), 374-383.

Moser, D. V., \& Martin, P. R. (2012). A Broader Perspective on Corporate Social Responsibility Research in Accounting. The Accounting Review, 87(3), 797-806.

Moskowitz, M. (1972). Choosing Socially Responsible Stocks. Business and Society Review, 1, 71-75. 
Nelling, E., \& Webb, E. (2009). Corporate social responsibility and financial performance: the 'virtuous circle' revisited. Review of Quantitative Finance \& Accounting, 32(2), 197-209.

Nissim. D., \& Ziv, A. (2001). Dividend changes and future profitability. The Journal of Finance, 56(6), 2111-2133.

Orlitzky, M., Schmidt, F. L., \& Rynes, S. L. (2003). Corporate Social and Financial Performance: A Meta-Analysis. Organization Studies, 24(3), 403-441.

Pava. M., \& Krausz, J. (1996). The Association between Corporate Social Responsibility and Financial Performance: The Paradox of Coaxial Cost. Journal of Business Ethics, 15, 321-357.

Prior, D., Surroca, J., \& Tribo, J. (2008). Are socially responsible managers really ethical? Exploring the relationship between earnings management and corporate social responsibility. Corporate Governance, 16(3), 160-177.
Richardson, J. (2000). Information Asymmetry and Earnings Management: Some Evidence. Review of Quantitative Finance and Accounting, 15, 325-347.

Trueman, B., \& Titman, S. (1988). An Explanation for Accounting Income Smoothing. Journal of Accounting Research, 26(supplement), 127-139.

Tsoutsoura, M. (2004). Corporate Social Responsibility and Financial Performance. Working Paper. University of California, Berkeley.

Waddock, S. A., \& Graves, S. B. (1997). The Corporate Social Performance-Financial Performance Link. Strategic Management Journal, 18(4), 303-319.

Ziebart, D.A. (1990). The Association between Consensus of Beliefs and Trading Activity Surrounding Earnings Announcements. The Accounting Review, 65(2), 1990, 477-488. 